\title{
Dziedziczenie urzędów w austriackim rodzie von Puchheim
}

\section{Wprowadzenie}

W niniejszej publikacji zamierzamy po raz pierwszy zmierzyć się z dziejami rodu von Puchheim. Zajęcie się tym zagadnieniem marginalnie zapowiadaliśmy w publikacjach o innych rodach wywodzących się ze wspólnego z tym rodem pnia. Pamiętać trzeba, że uczony, który podejmuje się tego zadania wdaje się w ogromne przedsięwzięcie, gdyż wspomniany ród rycerski jest jednym z bardziej rozrodzonych rodów w Europie. W celu uniknięcia powtórzeń zmuszeni jesteśmy do odesłania do naszych wcześniejszych publikacji na ten temat ${ }^{1}$. Tutaj wspomnimy tylko ogólnie, że protoplastą tego rodu była bardzo enigmatyczna postać z X wieku, mianowicie rycerz Dietger z Dern (Dehrn), domniemany fundator kolegiaty św. Lubencjusza w Dietkirchen (Hesja-Nassau). Nie jest $w$ stu procentach pewne, że ród von Puchheim wywodzi się od rodu von Dehrn, ale związek taki domniemywał już w wieku XVIII słynny genealog Johannes Sinapius². W tym przypadku rozstrzygającą kwe-

${ }^{1}$ T. Kruszewski, Rycerz Dietger z Dehrn i jego ślassy potomkowie do końca średniowiecza, AUWr, No 3602, Prawo CCCXVI/2, SHP, Wrocław 2014, s. 65-92; tenże, Ród wolnego rycerstwa Rzeszy Frei von Dehrn w stużbie hrabiów von Nassau. Studium historycznoprawne $i$ genealogiczne [złożone do druku], gdzie zmieniliśmy poglądy w niektórych kwestiach z pierwszej, podanej tu publikacji.

${ }^{2}$ J. Sinapius, Schlesischer Curiositäten Erste Vorstellung, Darinnen die ansehnlichen Geschlechter Des Schlesischen Adels, Mit Erzehlung Des Ursprungs, der Wappen, Genealogien, der qualificirtesten Cavaliere, der Stamm-Häuser und Güter beschrieben, Und dabey viele, bißhero ermangelte Nachrichten von Edlen Rittern und löblichen Vor-Eltern, aus alten brieflichen Urkunden und bewährten MSCtis zum Vorschein gebracht werden. Fleischerische Druckerey, Leipzig 1720 [cyt. dalej: J. Sinapius I], s. 179. 
stią jest wspólny herb, bardzo rzadki, przedstawiający trzy snopki zboża w układzie 2:1 na błękitnej (w wypadku rodu von Puchheim niekiedy też czarnej) tarczy.

\section{Stan badań}

Podejmujący się badań nad rodem von Puchheim musi skonstatować istnienie szeregu opracowań na temat owego rodu. Wpierw pojawiło się dzieło słynnego XVII-wiecznego genealoga Bucelinusa (Gabriela Bucelina), który w tomie I (w części trzeciej), po raz pierwszy podjął się wywiedzenia rodowodu rodu von Puchheim ${ }^{3}$. Rozwinął tę tematykę w tomie II, w jego części drugiej ${ }^{4}$ Pojawia się tu tajemniczy Aleksander Cumineus de Puchheim, uczestnik trzeciej wyprawy krzyżowej u boku króla Anglii Ryszarda Lwie Serce i razem z nim uwięziony w Austrii podczas powrotu do ojczyzny. Jego potomkowie są już jednak przywoływani w formie znanej nam z literatury XIX-wiecznej.

Punktem odniesienia jest już $\mathrm{w}$ większym stopniu XVIII-wieczne dzieło Johanna Hübnera, rektora szkoły św. Jana w Hamburgu, który dwukrotnie (1728 i 1766 r.) zmierzył się z rodem von Puchheim ${ }^{6}$. Dzieło to zostało opublikowane ze wsparciem króla Polski Augusta II Mocnego, na co niedwuznacznie wskazuje jego tytuł. Wiek XIX przyniósł jak na razie dwa najlepsze dzieła dotyczące rodu von Puchheim. Autorem pierwszego jest J. Albrecht ${ }^{7}$. Jednak dopiero w końcu tego stulecia ukazało się - jak na razie - jedyne kompleksowe opracowanie historii rodu von Puchheim.

${ }^{3}$ Gabrieli Bucelini Germania Topo-Chrono-Stemato-Graphica Sacra et Prophana, In qua Brevi Compendio Multa disticte explicantur, Ulmae 1655. Współcześnie oznacza się ten tom jako Bucelinus 1,3. Na s. 156 jest ogólnikowy rodowód.

${ }^{4}$ Gabrieli Bucelini Germania Topo-Chrono-Stemato-Graphica Sacra et Prophana, In qua Brevi Compendio Multa disticte explicantur, Ulmae 1662. Współcześnie oznacza się ten tom jako Bucelinus 2,2.

${ }^{5}$ Tamże, tom nie ma numeracji stron, w części (oznaczonej jako R3) poświęconej rodom, wśród rodów na literę „P $\mathrm{P}^{\prime}$ podaje Bucelinus tablice z rodem von Puchheim. Rodowód skrócony znalazł się też dalej, w części R4, s. 241 (tu jest numeracja stron).

${ }^{6}$ J. Hübner, Genealogische Tabellen nebst darzu gehörigen Genealogischen Fragen, zur Erläuterung der politischen Historie, mit sonderbahrem Fleiße zusammen getragen, und vom Anfange bis auf diesen Tag continuiret. Dritter Theil. Mit Königl. Polnischen und Churfl. Sächsischen sonderbahrem Privilegio, Lepzig 1728, tab. 775-779. Drugie wydanie zob. Leipzig 1766, tab. 775-779, wyraźnie ulepszone i poprawione.

${ }^{7}$ J. Albrecht, IV. Ahnentafel. 31. Die Puchheime, [w:] Taschenbuch für die vaterländische Geschichte. Herausgegeben durch die Freyherren von Hormayr und Mednyansky. Zehnter Jahrgang, Wien 1829, s. 19-52. 
Autorem jego jest wybitny znawca austriackiej szlachty Franz Karl Wißsgrill. Dzieło swoje opublikował w dwóch częściach ${ }^{8}$. Wiek XX nie może poszczycić się niczym więcej niż doprecyzowaniem tego ostatniego dzieła. Gustav Reingrabner zajął się tylko jedną z linii rodu' ${ }^{9}$ Najważniejsze XX-wieczne opracowanie odnoszące się do rodu von Puchheim, autorstwa Christopha Tepperberga, ciagle pozostaje jedynie maszynopisem dostępnym $\mathrm{w}$ uniwersyteckiej bibliotece $\mathrm{w}$ Wiedniu ${ }^{10}$. Ostatnim opracowaniem - już z wieku XXI - jest artykuł Maximiliana Weltina ${ }^{11}$.

\section{Pochodzenie rodu}

Dla Bucelinusa było oczywiste, że wspomniany wyżej towarzysz Ryszarda Lwie Serce był założycielem rodu von Puchheim. Aleksander Cumineus de Puchheim z roku 1193 - postać dość zagadkowa - był zdaniem Bucelinusa ojcem już całkowicie historycznej postaci Pilgrama I von Puchheim, którego wspomina pod rokiem $1235^{12}$. J. Hübner poszerzył informacje o Aleksandrze o informacje o jego małżeństwie $\mathrm{z}$ nieznaną z imienia przedstawicielką rodu von Meissau. Odrzucił też pogląd Bucelinusa, jakoby to Aleksander był ojcem Pilgrama I, jego zdaniem był tego ostatniego pradziadem, gdyż synem Aleksandra był Jan I, a synem tegoż Albert I, ojciec Pilgrama I ${ }^{13}$.

Badania nad pochodzeniem rodu von Puchheim, idąc tym tropem, wyprowadził na zupełne manowce J. Albrecht. Wywiódł on owego Aleksandra ze Szkocji (sic!) jako potomka niejakiego Dawida Cuminiusa

${ }^{8}$ F. K. Wißgrill, Puchheim, opublikowane w cyklu Schauplatz des niederösterreichischen landsässigen Adels vom Herren- und Ritter-Stande vom IX. bis zum Ende des XVIII. Jahrhunderts, [w:] Jahrbuch der k.k. heraldischen Gesellschaft Adler zu Wien, Jahrgang XIV, Wien 1887, s. 130-160; Jahrgang XIX. und XX., Wien 1889-1890, s. 153-211.

${ }^{9}$ G. Reingrabner, Die Herren von Puchheim auf Horn und Wildberg. Beiträge zu ihrer Genealogie, „Das Waldviertel, Neue Folge” 1965, Nr. 1/2, s. 4-10 [cyt. dalej: G. Reingrabner, cz. I] oraz tenże, Die Herren von Puchheim auf Horn (Fortsetzung und Schluß), „Das Waldviertel, Neue Folge" 1965, Nr. 3/4, s. 46-58 [dalej: G. Reingrabner, cz. II].

${ }^{10} \mathrm{Ch}$. Tepperberg, Die Herren von Puchheim im Mittelalter. Beiträge zur Geschichte des landsässigen Adels von Niederösterreich, Wien 1978 [maszynopis rozprawy doktorskiej oznaczony sygn. D. 21.531 w bibliotece uniwersyteckiej w Wiedniu].

${ }^{11}$ M. Weltin, Die Anfünge der Herren von Puchheim in Niederösterreich, [w:] Festschrift Heide Dienst zum 65. Geburtstag. Heausgeggeben von Anton Eggendorfer, Christian Lackner und Wilibald Rosner, St. Pölten 2004, s. 189-209.

${ }^{12}$ Bucelinus 2,2, część R3.

${ }^{13} \mathrm{~J}$. Hübner, 1728; 1766, tab. 775. 
z około 700 roku $^{14}$. Dalej popierał ustalenia Hübnera, choć z wątpliwościa, czy Jan I był synem Aleksandra ${ }^{15}$.

$Z$ tego typu poglądami polemizował F. K. Wißgrill, który zauważył ród Nobiles de Wenni w hrabstwie Rebegau lub Rebgau (obecnie Regau) w pobliżu Böcklabrucku. To ostatnie miasto leży w Górnej Austrii i jest siedzibą powiatu. To właśnie w jego pobliżu znajduje się potężny zamek Puchheim (obecnie w granicach miasta Attnang). To właśnie w tych okolicach około roku 1070 pojawił się tajemniczy rycerz Udalryk = Adalryk = Ulryk I (Adalricus) de Wengi (Wenge), któremu w przywileju król rzymski Henryk IV „nobilowi naszemu Udalrykowi de Wengi” nadał na rozkaz monarchy czynsz w wysokości pięciu fenigów za roczną służbę w dobrach w parafii Ranshofen, należących do kobiety imieniem Grotta i jej potomstwa ${ }^{16}$. "Oulric de Buchenheim" żył jeszcze około 1140 r. ${ }^{17}$ Wenge to dawna nazwa jednego z najsłynniejszych austriackich klasztorów benedyktyńskich Mondsee $^{18}$. Ostatnio nauka odkryła jeszcze Regelinta de Puchaim (z lat 1098-1137) niewątpliwie drugiego, młodszego brata Ulryka $\mathrm{I}^{19}$. To odkrycie pozwala nam umiejscowić $\mathrm{w}$ rodzie von Puchheim ustalonych przez Christopha Tepperberga braci Adalberta i Pero von Puchheim, jako darczyńców dóbr katedry św. Piotra w Salzburgu. Uznał ich za krewnych Pilgrima I, raczej nie za jego braci. Naszym zdaniem byli to bracia stryjeczni. Pero przekazuje swoją donację wraz z żoną Gizelą 20 . Tę ostatnią parę autor czyni rodzicami Konrada I - słusznie naszym zdaniem - wyłączając tę osobę spośród dzieci Pilgrima I. Ulryk I w naszej opinii to potomek Dietgera z Dehrn w czwartym pokoleniu, na równi z braćmi Fryderykiem i Rucherem z Dern, o których pisaliśmy już dwukrotnie.

W następnym pokoleniu dostrzegł Wißgrill braci Pilgrima I i Hartmanna de Buchheim (Puchheim). Znał ich już J. Albrecht określając ich jako darczyńców klasztoru w Garsten w Górnej Austrii, co zatwierdził w roku 1108 margrabia Styrii Ottokar II ${ }^{21}$. Dokument dokładnie cytuje też F. K. Wißgrill22. W tekście oraz w tablicy genealogicznej I podał on, że Pilgrim I miał za żonę Gerbirgę de Rotinke (Rottingen) ${ }^{23}$. Jednak Ch. Tep-

\footnotetext{
${ }^{14}$ J. Albrecht, IV. Ahnentafel..., s. 20.

${ }^{15}$ Tamże, s. 21.

${ }^{16}$ F. K. Wißgrill, XIV, s. 130.

${ }^{17} \mathrm{http}: / /$ www.puchheim.de/index.php?id=0,22 [dostęp: 16.07.2015].

${ }^{18}$ Ostatecznie wykazał to Ch. Tepperberg, Die Herren..., s. 5. Weng leży koło Kösten-

${ }^{19} \mathrm{http}: / / w w w . p u c h h e i m \cdot d e / i n d e x . p h p ? i d=0,22$ [dostęp: 16.07.2015].

${ }^{20}$ Ch. Tepperberg, Die Herren..., s. 6.

${ }^{21} \mathrm{~J}$. Albrecht, IV. Ahnentafel..., s. 20.

${ }^{22}$ F. K. Wißgrill, XIV, s. 130.

${ }^{23}$ F. K. Wißgrill, XIX-XX, s. 207. Zob. też dalej tenże, XIV, s. 131.
} dorf. 
perberg w maszynopisie rozprawy doktorskiej wykazał, że owa Gebirg von Roting, to żona Konrada I, który okazał się jednak synem brata stryjecznego Pilgrima I (zob. niżej) ${ }^{24}$.

Jak udowodnił F. K. Wißgrill Pilgrimus I de Wenge, de Buchheim, jest zasadniczym założycielem tego, jednego z najpotężniejszych, austriackiego rodu ${ }^{25}$. XIX-wieczny badacz z iście benedyktyńską cierpliwością prześledził XII-wieczne dokumenty, by odnaleźć w nich siedmiu synów Pilgrima I. Na dokumencie wystawionym przez Engilrama de Telingen, w którym ten ostatni ofiarowuje dobra Telingen, Neztal i Hobestorf klasztorowi Benedictbeuren, dla zapewnienia spokoju duszy swojego ojca i jego przodków, datowanego na lata 1138-1168 jako świadek pojawia się Heidenricus de Bouchaim. Ten Henryk I jest - zdaniem F. K. Wißgrilla - najstarszym synem Pilgrima I i przodkiem wszystkich przedstawicieli rodu w Austrii ${ }^{26}$. Drugim dzieckiem Pilgrima I jest Pernhardt de Bucheim (Bernard I de Puchheim). Pojawia się jako świadek na dokumencie wystawionym około roku 1170 przez Adelajdę de Corpheim, wraz z jej dziećmi: Roudwartem, Helechą, Gerbirtem i Irmgarda, w którym podarowali oni dobra klasztorowi Aspach ${ }^{27}$. Trzecim dzieckiem (synem) według wzmianki Wißgrilla był Arnold I de Puchheim. Nowsze badania w pełni to potwierdzają: "Arnoldus de Pvochain" świadkował na dokumentach $\mathrm{z}$ lat $1190-1192^{28}$.

Czwarty syn Pilgrima I, według Wißgrilla, Konrad I von Puchheim jest wymieniony jako świadek ważnego dokumentu - fundacji monastyru w Krems, który ogłosił Dypold, bp Passawy 26 sierpnia 1173 r. ${ }^{29}$ W tym samym roku świadkuje na dokumencie tegoż samego biskupa, w którym zatwierdzono zrzeczenie się na rzecz klasztoru Admont winnicy, podjęte wspólnie z córką Kunegundą którego dokonał hr. Liutold von Plain. Występuje tam jako syn Gerbirgi „de Rotinki”. Jest to jedyna wzmianka źródłowa o nieje ${ }^{30}$. Wißgrill jednak - jak udowodnił Tepperberg - wszystko pomieszał - te dokumenty nie dotyczą nawet Konrada I, lecz jego syna Konrada II (sam podaje szereg kolejnych z lat 1167-1183). Istnienie Konrada I to właściwie domysł Tepperberga, bo dokumenty doty-

${ }^{24}$ Ch. Tepperberg, Die Herren..., s. 6.

${ }^{25}$ Także Ch. Tepperberg, Die Herren..., s. 5 nie ma co do tego żadnych wątpliwości.

${ }^{26}$ F. K. Wißgrill, XIV, s. 131.

${ }^{27}$ Tamże, s. 131.

${ }^{28} \mathrm{http}: / / w w w . p u c h h e i m . d e / i n d e x . p h p ? i d=0,22$ [dostęp: 16.07.2015].

${ }^{29} \mathrm{~J}$. Albrecht, IV. Ahnentafel..., s. 20, F. K. Wißgrill uściśla jednak, że chodzi tu tylko o nadanie probostwa "Chiriperch" temu monastyrowi, zob. F. K. Wißgrill, XIV, s. 131.

${ }^{30}$ F. K. Wißgrill, XIV, s. 131. O Pilgrimie I i jego żonie zob. Ch. Tepperberg, Die Herren..., s. 5 i n. 
czące Konrada II zwą go "Conradus junior" ${ }^{1}$. Pero von Puchheim miał jednak rodzeństwo, z którego najpewniejszymi postaciami jako brat i siostra Konrada Starszego występowali na dokumencie datowanym około roku 1140 Henryk z Schalkham i jego siostra Adelajda (Alheit) de Weng. Konrad Młodszy świadkuje razem z krewnymi "Ortolfus de Pucheim, Rapoto de Pucheim, ...., Ernprecht de Pucheim" (lata 1147-1193) ${ }^{32}$. Naszym zdaniem to także jego stryjowie. Mało prawdopodobne, by byli to kolejni synowie Pilgrima I. Ostatnim, siódmym synem Pilgrima II nie był natomiast Gebno de Puecheim - jak chciał Wißgrill - świadkujący na dokumentach z lat 1190-1215 ${ }^{33}$. Jest to niewattpliwie syn Konrada Młodszego i ostatni przedstawiciel tej drugiej linii ${ }^{34}$.

Piąty syn Pilgrima I Ulryk II von Puchheim (Oulricus de Buchheim) występuje jako świadek na dokumencie z roku 1185, w którym niejaki Engilschalk w imieniu swojego pana Alberta von Wihsilburch (Weixelburg) nadaje klasztorowi Admont studnię wraz z dziedzińcem w Riedmark (Górna Austria) ${ }^{35}$. Był to prawdopodobny przodek rodu von Buchheim (oraz pochodzącego od niego rodu von Sommerfeld) na Śląsku, o którym wzmiankuje Johannes Sinapius ${ }^{36}$.

Szóstym synem jest - zdaniem Wißgrilla - Pilgrim II. W roku 1190 ks. Styrii Ottokar IV poświadcza przynależność do kanoników katedry salzburskiej osady "Werchendorf” nad rzeką Drau. Świadkiem na tym dokumencie jest Pilgrimus de Puchheim. Jako świadka wymienia go także dokument $\mathrm{z}$ tego samego roku, w którym władca Austrii Leopold V Cnotliwy zatwierdza to nadanie. W roku 1194 nowy władca Leopold VI Sławny zatwierdza nadanie wsi "Sprezze” w zamian za dziesięciny ze wsi „Rudmares” klasztorowi Zwettl, tu także świadkuje Pilgrim II. Jeszcze w roku 1196 władca austriacki Fryderyk I Chrześcijanin powołał Pilgrima II na świadka przywileju dla klasztoru Erla, wydanego na prośbę opatki Adelajdy o zwolnienie dóbr klasztornych z płacenia myta na drodze między Stein i Ipspruch ${ }^{37}$. Jednak, jak wykazał Ch. Tepperberg, Pilgrim II występuje już ze swym ojcem na dokumentach archidiecezji salzburskiej z roku $1140^{38}$. Zaliczył go do rycerstwa służebnego (mini-

\footnotetext{
${ }^{31}$ Ch. Tepperberg, Die Herren..., przyp. 25 na s. 90.

${ }^{32}$ Tamże, s. 6.

${ }^{33}$ F. K. Wißgrill, XIV, s. 131.

${ }^{34}$ Ch. Tepperberg, Die Herren..., s. 7.

${ }^{35}$ F. K. Wißgrill, XIV, s. 131.

${ }^{36}$ J. Sinapius I, Schlesischer Curiositäten..., s. 919.

${ }^{37}$ F. K. Wißgrill, XIV, s. 131.

${ }^{38}$ Ch. Tepperberg, Die Herren..., s. 6. Poświęca mu zresztą obszerniejsze uwagi na
} s. 7-10. 
steriałów) w Styrii ${ }^{39}$. Przypomnijmy pokrótce, czym charakteryzowała się ta grupa w Świętym Cesarstwie Rzymskim Narodu Niemieckiego. Część czeladzi nadwornej, określana mianem ministeriałów, rozwinęła się w wieku XI. Panowie zwierzchni zaczęli ich osadzać na ziemi, zwalniając od świadczeń gruntowych, w zamian za konną służbę wojskową $\mathrm{w}$ forpoczcie pana feudalnego. Były to tzw. lenna służbowe (Dienstlehen), zwane też - szczególnie odnośnie do ministeriałów władców, lennami dworskimi (Hoflehen). W tych warunkach sytuacja ministeriałów upodabniała się do stosunków między seniorem i wasalem ${ }^{40}$. Upływ czasu powodował coraz częściej zbliżanie się ministeriałów do warstwy rycerskiej. Do ministeriałów zaczęli zgłaszać się także młodsi rycerze, którzy $\mathrm{z}$ powodu dziedziczenia lenna $\mathrm{w}$ formie primogenitury, byli pozbawieni ziemi. Tą drogą także kroczyli Puchheimowie, byli to tzw. ministeriałowie z zastrzeżeniem (Vorbehaltsministerialen) i tak narodziła się warstwa tzw. niższej szlachty (der niedere Adel) ${ }^{41}$.

\section{Ród urzędników}

Wspomniane wyżej świadkowanie Puchheimów na dokumentach Babenbergów, władców Austrii, nie przyniosło im pełnienia żadnych urzędów w państwie. Przełomem okazało się przejściowe podporządkowanie Austrii królowi czeskiemu Przemysłowi Ottokarowi II, który w 1276 r. Albertowi I von Puchheim, zwanemu Albero (zm. w 1308 r.) powierzył urząd dziedzicznego stolnika dworu w Veltsperg i związane z tym urzędem dobra w Orth. Albero I był według Wißgrilla wnukiem Henryka I, a według Albrechta jego prawnukiem, choć ojcostwo Jana I oznaczył znakiem zapytania ${ }^{42}$. Ch. Tepperberg poświęcił Alberowi I (błędnie zwanemu przez niego II) wiele istotnych uwag, do których z racji ograniczonych ram tej publikacji nie będziemy się mogli odnieść ${ }^{43}$. Ten

\footnotetext{
${ }^{39}$ Tamże, s. 12-13.

${ }^{40}$ K. Koranyi, Powszechna historia państwa i prawa w zarysie, Warszawa 1955, t. II, Epoka feudalizmu, s. 115.

${ }^{41}$ Tamże, s. 116.

${ }^{42}$ F. K. Wißgrill, XIV, s. 132, wyraźnie odrzuca istnienie Jana I. J. Hübner, 1728; 1766, tab. 775 różni się także w kwestii żony Alberta I, zwie ją Weroniką Jogin, jest to postać fikcyjna, co wykazał F. K. Wißgrill, gdyż żoną Alberta I była Agnieszka von Liebenstein, zob. F. K. Wißgrill, XIV, s. 135. Opis wszystkich źródeł, w których występuje Albert I, zajmuje s. 132-135.

${ }^{43}$ Ch. Tepperberg, Die Herren..., s. 16-25.
} 
ostatni autor wiąże wspomniany wyżej fakt z dziedzicznym pełnieniem od tej chwili urzędu najwyższego stolnika Austrii aż po $1711 \mathrm{r}^{44}$

Od jego syna Pilgrama I, ur. 1280, zm. 1341 (u Wißgrilla data śmierci $1343 \mathrm{r}^{45}$ ), rozpoczęła się trwająca 400 lat służba rodu von Puchheim dynastii habsburskiej ${ }^{46}$. Na dworze praskim cesarz Albrecht I wystawił 11 listopada 1306 r. przywilej, w którym nadał Pilgramowi I lenna Kaltenbrunn i Petersdorf (oba leżą w Styrii) oraz hrabstwo Lawenz na Węgrzech $^{47}$. Występuje w szeregu dokumentów Albrechta II Habsburga jako najwyższy stolnik monarchii ${ }^{4}$. Najstarszym synem Pilgrama I był Henryk $\mathrm{IV}^{49}$. Pełnił on funkcję dowódcy wojsk Albrechta II, zm. jak wykazał Wißgrill, w roku $1343^{50}$. Kolejnym z synów Pilgrama I był Albert III, który na dworze wiedeńskim uzyskał szereg istotnych urzędów. Był radcą ks. Albrechta II Habsburga, landwójtem Turgowii i Ergau (dzisiejsza Szwajcaria), w latach 1361-1362 starostą wojennym Rudolfa I Habsburga. Znacznie poszerzył swoje włości nabywając od Albrechta III Gottfriedschlag, Weissenbach, część lasu Losberskiego, nadano mu także lenno Saubersdorf w hrabstwie Regnitz ${ }^{51}$. Brat Alberta III Jan II w podziale braterskim otrzymał Blumenau, władztwo Lichtenwerth (ze słynnym zamkiem, leży w Tyrolu), St. Peter na Węgrzech ${ }^{52}$.

${ }^{44}$ Tamże, zob. s. 26-32. Trzeba także pamiętać o tekście M. Weltina, Die Anfänge..., który jest omówieniem wybranych dokumentów.

${ }^{45}$ F. K. Wißgrill, XIV, s. 138, choć z wątpliwościami.

${ }^{46}$ Por. szerzej Ch. Tepperberg, Die Herren..., s. 33-37.

${ }^{47}$ F. K. Wißgrill omawia Pilgrama I na wielu stronach, zob. F. K. Wißgrill, XIV, s. 135-138. Zna też, tak jego poprzednicy, jego brata Alberta II, ale nie uznaje najmłodszego Fryderyka, zob. J. Hübner, 1728; 1766, tab. 775. Także małżeństwa Pilgrama I budzą kontrowersje. Pierwsza żona nosiła imię Elżbieta, według Hübnera była z rodu von Töttelbach, w czym błądzi, natomiast ani J. Albrecht, ani F. K. Wißgrill nie rozstrzygnęli, czy była ona z rodu von Pottendorf, czy też była córką Ulryka von Stubenberg. Natomiast odnośnie do drugiej żony F. K. Wißgrill wykazał, że informacje na ten temat u Hübnera, iż była to Kunegunda Stuchs von Trautmannsdorf są prawdziwe, a pomylił się tym razem J. Albrecht, zwąc ją Kunegundą Rubaßin; J. Hübner, 1728; 1766, tab. 775; J. Albrecht, IV. Ahnentafel..., s. 23-24; F. K. Wißgrill, XIV, s. 138.

${ }^{48}$ F. K. Wißgrill, XIV, s. 137.

${ }^{49}$ Szeroko omawia te kwestie Ch. Tepperberg, Die Herren..., s. 38-45.

${ }^{50}$ F. K. Wißgrill, XIV, s. 138. W odniesieniu do informacji o jego małżeństwie wszyscy badacze są jednomyślni, ożenił się on z Elżbietą Albertą von Rauhenstein, zob. J. Hübner, 1728; 1766, tab. 775; J. Albrecht, IV. Ahnentafel..., s. 23; F. K. Wißgrill, XIV, s. 138.

${ }^{51}$ Informacje na jego temat podają: J. Hübner, 1728; 1766, tab. 775; J. Albrecht, IV. Ahnentafel..., s. 26; F. K. Wißgrill, XIV, s. 139 i n. Wszyscy są też zgodni, że był on dwukrotnie żonaty, po raz pierwszy z Anna, córką Pawła von Markersdorf, a po raz drugi ze Scholastyka, córką Gundakera von Starhemberg.

${ }^{52}$ Informacje na jego temat podają: J. Hübner, 1728; 1766, tab. 775; J. Albrecht, IV. Ahnentafel..., s. 26; F. K. Wißgrill, XIV, s. 146 i n. Wszyscy są też zgodni, że był on żonaty z Zofią von Kappell. 
Czterech synów Alberta III sięgnęło wysokich stanowisk, które od tej chwili stały się w ich liniach dziedziczne ${ }^{53}$. Pierworodny syn Pilgram III, został najwyższym stolnikiem Albrechta III, a potem IV. Za małoletności tego ostatniego Pilgram III był regentem Austrii. Urodził się w roku 1338, zmarł w 1402 roku $^{54}$. Od niego wywodzi się Dom Gellersdorf rodu. Albert IV Starszy był założycielem Domu Gmund (od następnego pokolenia zwanego Gellersdorf ${ }^{55}$, natomiast jego brat przyrodni Albert V Młodszy został w roku 1405 najwyższym stolnikiem i starostą Karyntii. Był on założycielem Domu Raabs ${ }^{56}$. Ostatni, Jerzy I, został w roku 1407 najwyższym stolnikiem arcyksięcia Styrii i Krainy Ernesta Żelaznego, a od arcyksięcia Fryderyka z Pustą Kieszenią otrzymał sędziostwo Krummbach. Zmarł jednak bezpotomnie ${ }^{57}$. Po nim tytuły odziedziczył bratanek Wilhelm I (syn Alberta IV), najwyższy stolnik i starosta krajowy Styrii w Grazu. Był dziedzicem państwa Gmund, a także dóbr Hallabrunn, Loipersdorf, Wentlingen, Traißkirchen, Neudorf i Pfaffstädten ${ }^{58}$. Jego dziedzicem był syn - imiennik Wilhelm II, który zmarł jako radca nadworny cesarza rzymskiego Fryderyka III, cesarski starosta polny i wyższy stolnik Styrii. Wilhelm II nie pozostawił jednak potomstwa z prawego łoża ${ }^{59}$.

${ }^{53}$ Tym właśnie kwestiom poświęcił Ch. Tepperberg ostatnią część rozprawy doktorskiej, zob. Die Herren..., s. 46-82.

${ }^{54}$ Informacje na jego temat podają: J. Hübner, 1728; 1766, tab. 775; J. Albrecht, IV. Ahnentafel..., s. 28; F. K. Wißgrill, XIV, s. 149 i n. Wszyscy są też zgodni, że był on żonaty z Małgorzata, córką Henryka von Meissau.

${ }^{55}$ Informacje na jego temat podają: J. Hübner, 1728; 1766, tab. 775; J. Albrecht, IV. Ahnentafel..., s. 28-29; F. K. Wißgrill, XIV, s. 152 i n. Wszyscy są zgodni, że był on dwukrotnie żonaty, po raz pierwszy z Anną Katarzyną (Wißgrill zna tylko to drugie imię), córką Eberharda von Waltsee, a po raz drugi z Anną von Liechtenstein; tamże.

${ }^{56}$ Informacje na jego temat podają: J. Hübner, 1728; 1766, tab. 778; J. Albrecht, IV. Ahnentafel..., s. 29-30 (ten nic nie wie o jego żonie); F. K. Wißgrill, XIV, s. 158 i n. Hübner i Wißgrill są też zgodni, że był on żonaty z Małgorzata, córką Chatolda (tak u Hübnera, u Wißgrilla Katolda) von Eckartsau; tamże.

${ }^{57}$ Informacje na jego temat podają: J. Hübner, 1728; 1766, tab. 775; J. Albrecht, IV. Ahnentafel..., s. 30; F. K. Wißgrill, XIV, s. 158 i n. Wszyscy są zgodni, że był on żonaty z Katarzyną von Ehrenfels; tamże.

${ }^{58}$ Informacje na jego temat podają: J. Hübner, 1728; 1766, tab. 775; J. Albrecht, IV. Ahnentafel..., s. 32-33; F. K. Wißgrill, XIV, s. 154 i n. Wszyscy są też zgodni, że był on dwukrotnie żonaty, po raz pierwszy z Elżbietą córką Henryka von Zeltking, a po raz drugi z Dorota, córką Wolfganga Streun von Schwarzenau; tamże.

${ }^{59}$ Informacje na jego temat podają: J. Hübner, 1728; 1766, tab. 775; J. Albrecht, IV. Ahnentafel..., s. 33, F. K. Wißgrill, XIV, s. 155 i n. Wszyscy są też zgodni, że był on żonaty z Dorotą nieznanego rodu; tamże. 


\section{Dom Gellersdorf ${ }^{60}$}

Dom ten, założony przez Pilgrama III Seniora, w następnym pokoleniu podzielił się na dwie linie. Starsza, która wywodziła się od Pilgrama IV Juniora (zm. 1427 r.) i młodszą, której założycielem był młodszy syn Jan V. Od tego pokolenia ród Puchheim awansował do najwyższych pozycji w państwie, na równi z rodami von Liechtenstein i von Starhemberg, z którymi wchodził w liczne koligacje. Pilgram IV wydzierżawił od Habsburgów Litschau, Ilmau, Fondort, a w roku 1407 kupił władztwo Gellersdorf (Dolna Austria, powiat Hollabrunn), skąd wzięła się nazwa domu. W roku 1413 Pilgram IV został wyższym marszałkiem austriackich stanów, a w roku 1421 od cesarza Zygmunta Luksemburczyka otrzymał nową tarczę herbową z czerwoną opaską i srebrnym polem ${ }^{61}$. Jego syn Pilgram V został radcą Albrechta V Habsburga, zmarł w roku $1445^{62}$. Ostatnim z tej linii był syn Pilgrama V Zygmunt I, będący starostą polnym cesarza Fryderyka III Habsburga ${ }^{63}$.

Wspomniany wyżej Jan V (1371-1438), współdziedziczył wyżej wymienione dobra. Był cesarskim radcą i starostą polnym ${ }^{64}$. Jego syn Jan VI (1416-1443) przed kuzynem Zygmuntem pełnił analogiczny urząd na dworze Fryderyka III ${ }^{65}$. Od jego syna Hartneida I, który przejął po młodszej linii urząd najwyższego stolnika, stał się to urząd dziedziczny. Hartneid I urodził się około roku 1440, zmarł w roku $1495^{66}$. Był panem dziedzicznym na Gellersdorf i Horn. Ta ostatnia miejscowość jest obecnie siedzibą powiatu.

${ }^{60}$ Obecnie Göllersdorf.

${ }^{61}$ Informacje na jego temat podają: J. Hübner, 1728; 1766, tab. 776; J. Albrecht, IV. Ahnentafel..., s. 30-31; F. K. Wißgrill, XIX/XX, s. 153 i n. Wszyscy są też zgodni, że był on żonaty z Anną von Wohlfurth (lub Wolfsruck); tamże.

${ }^{62}$ Informacje na jego temat podają: J. Hübner, 1728; 1766, tab. 776; J. Albrecht, IV. Ahnentafel..., s. 31; F. K. Wißgrill, XIX/XX, s. 155 i n. Wszyscy są też zgodni, że był on żonaty z Urszula, córką Gundakera VII von Starhemberg (jego imienia Hübner nie znał jeszcze w wydaniu z 1728 r.); tamże.

${ }^{63}$ Informacje na jego temat podają: J. Hübner, 1728; 1766, tab. 776; J. Albrecht, IV. Ahnentafel..., s. 31; F. K. Wißgrill, XIX/XX, s. 157 i n. Wszyscy są też zgodni, że był on bezżenny; tamże.

${ }^{64}$ Informacje na jego temat podają: J. Hübner, 1728; 1766, tab. 776; J. Albrecht, IV. Ahnentafel..., s. 32; F. K. Wißgrill, XIX/XX, s. 157 i n. Wszyscy są zgodni, że był on żonaty z Wallburgą (Willburgą?), córką Albrechta von Pottendorf; tamże.

${ }^{65}$ Informacje na jego temat podają: J. Hübner, 1728; 1766, tab. 776; J. Albrecht, IV. Ahnentafel..., s. 32, F. K. Wißgrill, XIX/XX, s. 158. Wszyscy są zgodni, że był on żonaty z Dorota, córką Hartneida (imienia tego nie zna Hübner) von Pottendorf (dzięki czemu imię to przeszło do rodu von Puchheim); tamże.

${ }^{66}$ Informacje na jego temat podają: J. Hübner, 1728; 1766, tab. 776; J. Albrecht, IV. Ahnentafel..., s. 34; F. K. Wißgrill, XIX/XX, s. 158 i n. Wszyscy są zgodni, że był on żonaty z Dorotą von Wildungsmauer; tamże. 
Starszym synem Hartneida I był Wit I (zm. 1483 r.), założyciel domu Horn (zob. niżej) ${ }^{67}$, natomiast młodszy Jan VIII, najwyższy stolnik Austrii, zmarł w roku 1525. Ten ostatni dziedziczył w Gellersdorf ${ }^{68}$. Spośród synów Jana VIII zwróćmy uwagę na najstarszego Michała Ludwika, założyciela starszej linii Gellersdorf i najmłodszego Wolfganga, zwanego Wolfem, założyciela linii młodszej ${ }^{69}$. Michał Ludwik (zm. 1580 r.) spędził młode lata w Krakowie na dworze Zygmunta I Starego, będąc królewskim dworzaninem. Po śmierci ojca został najwyższym stolnikiem i radcą cesarza Karola V, a potem Ferdynanda I ${ }^{70}$. Najważniejszym z jego synów był Jan Krzysztof I, zm. 6 października 1594 r., radca rządowy cesarza Rudolfa II i nadradca kamery dworskiej ${ }^{71}$. Jego następcą został Jan Krzysztof II, najwyższy stolnik, komornik, nadworny radca wojenny, pułkownik jazdy i piechoty, cekmistrz polny i obronny (ur. 1578 r., zm. w Wiedniu 17 września 1619 r. $)^{72}$. Potężna kariera tej linii rodu zakończyła się na śmierci dwóch jego synów - nie doczekali się oni męskich następców, którzy by ich przeżyli. Pierwszym z braci był Jan Rudolf, ur. 1600 r., zm. 1651 r., mianowany hrabią Rzeszy (Reichsgraf) von Puchheim, dziedziczny cześnik Austrii za Ferdynanda III, najwyższy komornik ${ }^{73}$. Jego młodszym bratem był Jan Krzysztof III, zm. 6 października 1657 r., hrabia Rzeszy von Puchheim, dziedziczny wyższy stolnik Austrii, cesarski tajny

${ }^{67}$ Informacje na jego temat podają: J. Hübner, 1728; 1766, tab. 776; J. Albrecht, IV. Ahnentafel..., s. 36; F. K. Wißgrill, XIX/XX, s. 160. Wszyscy są zgodni, że był on żonaty z Barbarą (tylko J. Albrecht przytacza błędne imię Ewa) Turnosch z Węgier; tamże.

${ }^{68}$ Informacje na jego temat podają: J. Hübner, 1728; 1766, tab. 777; J. Albrecht, IV. Ahnentafel..., s. 37; F. K. Wißgrill, XIX/XX, s. 166 i n. Wszyscy są zgodni, że był on żonaty z Barbara, córką Wolfganga Streun von Schwarzenau; tamże.

${ }^{69}$ Informacje na jego temat podają: J. Hübner, 1728; 1766, tab. 777; J. Albrecht, IV. Ahnentafel..., s. 37; F. K. Wißgrill, XIX/XX, s. 168 i n. Wszyscy są zgodni, że był on żonaty z Małgorzata, córką Franciszka, hr. Von St. Georgen und Pösing; tamże.

${ }^{70}$ Informacje na jego temat podają: J. Hübner, 1728; 1766, tab. 777; J. Albrecht, IV. Ahnentafel..., s. 40-41; F. K. Wißgrill, XIX/XX, s. 170 i n. Wszyscy są zgodni, że był on dwukrotnie żonaty: po raz pierwszy z Małgorzata, córką Dytryka von Hartisch z Miśni, po raz drugi z Poliksena, córką Wolfganga von Roggendorf; tamże.

${ }^{71}$ Informacje na jego temat podają: J. Hübner, 1728; 1766; tab. 777; J. Albrecht, IV. Ahnentafel..., s. 41; F. K. Wißgrill, XIX/XX, s. 171 i n. Wszyscy są zgodni, że był on żonaty z Małgorzata, córką Ludwika XVI Młodszego, hr. Oettingen-Oettingen; tamże.

${ }^{72}$ Informacje na jego temat podają: J. Hübner, 1728; 1766, tab. 777; J. Albrecht, IV. Ahnentafel..., s. 46-47; F. K. Wißgrill, XIX/XX, s. 172 i n. Wszyscy są zgodni, że był on żonaty z Zuzanna, córką barona Wilhelma von Hofkirchen, prezydenta ces. najwyższej nadzwyczajnej rady wojennej; tamże.

${ }^{73}$ Informacje na jego temat podają: J. Hübner, 1728; 1766, tab. 777; J. Albrecht, IV. Ahnentafel..., s. 47-48; F. K. Wißgrill, XIX/XX, s. 176 i n. Wszyscy są zgodni, że był on żonaty z Marią Elżbieta, córką hrabiego Pawła Sykstusa von Trautson; tamże. 
radca, feldmarszałek, wiceprezydent tajnej wyższej rady wojennej, rycerz Orderu Złotego Runa ${ }^{74}$.

Synem wspomnianego wyżej Wolfa był Jerzy V, zm. 1613 r., radca dworu cesarskiego za Rudolfa II, wyższy ochmistrz i stolnik, jego syn Otto Hermann, zm. 1626 r. pozostawił po sobie tylko żeńskie potomstwo ${ }^{75}$.

\section{Dom Horn}

Jan IX, syn Wita I, pan na Wiltpere i Horn, był marszałkiem, wyższym stolnikiem Dolnej Austrii, a potem jej regentem, zm. w roku $1544^{76}$. Jan IX pozostawił po sobie liczne potomstwo, z którego na uwagę zasługują dwaj synowie - Wit II Albrecht oraz Dytryk. Wit II Albrecht, dziedzic Horn, Kameth, Lentgruß i Roth, cesarski radca i wyższy stolnik, zmarł w roku 1584, nie doczekawszy się dziedzica ${ }^{77}$. Dytryk, pan na Wiltpere, po śmierci brata także na jego posiadłościach, zm. w roku $1589^{78}$. Jego potomstwo nie dzierżyło już jednak urzędów ${ }^{79}$.

\section{Dom Raabs}

184 Potomstwo Alberta V zapoczątkowało drugi potężny dom rodu von Puchheim. Z synów Alberta V na uwagę zasługuje Jerzy II, zm. w roku 1458, radca dworu i stolnik cesarski od roku 1435, potem też namiestnik

${ }^{74}$ Informacje na jego temat podają: J. Hübner, 1728; 1766, tab. 777; J. Albrecht, IV. Ahnentafel..., s. 48-49; F. K. Wißgrill, XIX/XX, s. 178 i n. Wszyscy są zgodni, że był on żonaty z Polikseną Maria, córką hrabiego Jana Ludwika von Leiningen-Dachsburg; tamże.

${ }^{75}$ Informacje na jego temat podają: J. Hübner, 1728; 1766, tab. 777; J. Albrecht, IV. Ahnentafel..., s. 37; F. K. Wißgrill, XIX/XX, s. 169 i n. Wszyscy są zgodni, że był on dwukrotnie żonaty: po raz pierwszy z Dorota, córką Jana von Biberstein, po raz drugi z Marią Friedlitzin; tamże.

${ }^{76}$ Informacje na jego temat podają: J. Hübner, 1728; 1766, tab. 776; J. Albrecht, IV. Ahnentafel..., s. 36; F. K. Wißgrill, XIX/XX, s. 160 i n. Wszyscy są zgodni, że był on żonaty z Anna, córką Ernesta von Seeburg, wdową po Michale von Eytzing; tamże. O Janie IX pisał też G. Reingrabner, cz. I, s. 5-6.

${ }^{77}$ Informacje na jego temat podają: J. Hübner, 1728; 1766, tab. 776; J. Albrecht, IV. Ahnentafel..., s. 37; F. K. Wißgrill, XIX/XX, s. 162 i n. Wszyscy są zgodni, że był on dwukrotnie żonaty: po raz pierwszy z Elżbietą córką barona Wolfganga von Kreigk lub Krayg (imię ojca podaje tylko Wißgrill), po raz drugi z Heleną, córką Jana Wilhema von Roggendorf; tamże. Zob. także G. Reingrabner, cz. I, s. 6-7.

${ }^{78}$ Informacje na jego temat podają: J. Hübner, 1728; 1766, tab. 776; J. Albrecht, IV. Ahnentafel..., s. 37; F. K. Wißgrill, XIX/XX, s. 164. Wszyscy są zgodni, że był on żonaty z Elżbietą Hoffmanin (Hoffmann von Grünbichl); tamże. Zob. także G. Reingrabner, cz. I, s. 7-8.

${ }^{79}$ Zob. także G. Reingrabner, cz. I, s. 8-10 oraz cz. II, s. 46-58. 
państwa ${ }^{80}$. Od jego trzech synów wywodzą się trzy główne linie domu Raabs. Najstarszym synem Jerzego II był Henryk IV (VI - różne numeracje), założyciel domu Litschau, zm. w roku 1478. Był on wyższym stolnikiem, kapitanem i radcą cesarskim, panem na Litschau ${ }^{81}$. Jego bratem był Jan VII, pan na Heidenreichstein, wyższy stolnik cesarza Maksymiliana I, zm. w roku 1518. Był on założycielem domu Heidenreichstein ${ }^{82}$. Ostatnim synem Jerzego II był Baltazar I, pan na Krummbach, zm. w roku $1504^{83}$.

Synem Henryka IV był Jerzy III, pan na Raabs, Dobersberg, Lichtenwörth, jednak jego całe potomstwo pochodzące $\mathrm{z}$ czterech żon wymarło jako dzieci ${ }^{84}$.

\section{Dom Heidenreichstein}

Jan VII pozostawił dwóch synów, którzy go przeżyli. Starszym był Pilgram VI, najwyższy stolnik dziedziczny, zm. 1534 (1542?) ${ }^{85}$. Przedstawiciele Domu Heidenreichstein nie pełnili w dalszych pokoleniach żadnych urzędów, tylko syn Pilgrama VI Otto Henryk za Ferdynanda I był

${ }^{80}$ Informacje na jego temat podają: J. Hübner, 1728; 1766, tab. 778; J. Albrecht, IV. Ahnentafel..., s. 33-34; F. K. Wißgrill, XIX/XX, s. 180-182. Wszyscy są zgodni, że był on trzykrotnie żonaty: po raz pierwszy z Praksedą, córką Ottona von Velben, po raz drugi z Elżbietą (imię to podaje tylko Wißgrill, u Albrechta i u Hübnera imię nieznane), córką Jana von Neuhaus z Czech, a po raz trzeci z Małgorzata, córką Henryka [Hinka] von Schwamberg; tamże.

${ }^{81}$ Informacje na jego temat podają: J. Hübner, 1728; 1766, tab. 778; J. Albrecht, IV. Ahnentafel..., s. 35; F. K. Wißgrill, XIX/XX, s. 183-185. Wszyscy są zgodni, że był on żonaty ze Swincką von Moschawitz; tamże.

${ }^{82}$ Informacje na jego temat podają: J. Hübner, 1728; 1766, tab. 778; J. Albrecht, IV. Ahnentafel..., s. 35-36; F. K. Wißgrill, XIX/XX, s. 186-187. Wszyscy są zgodni, że był on żonaty z Anna, córką Pankracego von Plankenstein-Neuburg; tamże.

${ }^{83}$ Informacje na jego temat podają: J. Hübner, 1728; 1766, tab. 779; J. Albrecht, IV. Ahnentafel..., s. 36; F. K. Wißgrill, XIX/XX, s. 190-191. Wszyscy są zgodni, że był on żonaty z Helena, córką Krzysztofa von Pottendorf; tamże.

${ }^{84}$ Informacje na jego temat podają: J. Hübner, 1728; 1766 (dokładniej niż 1728), tab. 778; J. Albrecht, IV. Ahnentafel..., s. 35; F. K. Wißgrill, XIX/XX, s. 185-186. Hübner podaje, że był on czterokrotnie żonaty (Albrecht i Wißgrill dostrzegają tylko jego czwartą żonę): po raz pierwszy z Katarzyną von Pottendorf, po raz drugi z Apolonią córką Weickhardta XII von Polheim, po raz trzeci z Małgorzata, córką Wolfganga von Stubendorf, wreszcie po raz czwarty z Magdalena, córką Ottona von Zelking; tamże.

${ }^{85}$ Informacje na jego temat podają: J. Hübner, 1728; 1766, tab. 778; J. Albrecht, IV. Ahnentafel..., s. 36 (ten podaje zupełnie błędne dane na temat jego bezpotomnej śmierci); F. K. Wißgrill, XIX/XX, s. 188. Informacje na temat jego małżeństwa są sprzeczne. Hübner i Wißgrill słusznie zwą ją Zofia, córką Jana Schirmers von Selß. Spotkać też można jej błędne imię Sabina, dodaje mu się jeszcze drugą żonę Małgorzatę, córkę Heidenreicha von Maissau. 
radcą cesarskim w Burgundii oraz sekretarzem państwa, zmarł w roku $1576^{86}$. Młodszy brat, Wilhelm III, pan na Waidhofen, zm. 1542, był cesarskim radcą i marszałkiem krajowym Dolnej Austrii w latach 1509-1514 oraz $1533-1541^{87}$. Jego potomstwo zmarło w młodym wieku.

\section{Linia Baltazara I}

Spośród siedmiorga dzieci Baltazara I trzeba zwrócić uwagę na synów - Krzysztofa III i Jerzego IV. Krzysztof III posiadał też dobra na Węgrzech (w komitacie Sopron), pełnił tam od roku 1498 funkcję dziedzicznego namiestnika, w roku 1522 został namiestnikiem w urzędzie marszałka krajowego Dolnej Austrii, a w latach 1522-1527 samym marszałkiem, $\mathrm{zm}$. w roku $1534^{88}$. Jego młodszy brat Jerzy IV był marszałkiem krajowym w latach 1527-1531, zm. w roku $1531^{89}$. Od Krzysztofa III pochodzi starsza linia domu Raabs. Starszym synem Krzysztofa III był Longin, wyższy stolnik, zm. w roku $1550^{90}$. Jako pierwszy w rodzie przyjął protestantyzm. Pozostawił po sobie jedyne dziecko Antoniego, który uzyskał tytuł barona von Puchheim zu Raabs und Krummbach, zmarłego bezpotomnie ${ }^{91}$. Młodszym synem Krzysztofa III był Erazm, ur. w 1518 r., zm. 16 czerwca

${ }^{86}$ Informacje na jego temat podają: J. Hübner, 1728; 1766, tab. 778; F. K. Wißgrill, XIX/ XX, s. 188. Informacje na temat jego małżeństwa są sprzeczne. Hübner w wydaniu z roku 1728 podaje błędnie, że była to Sabina von Seeburg. Już w wydaniu z roku 1766 poprawia się na Sabinę, córkę Sebastiana Joachima von Schlick, zostaje to podtrzymane w nowszych pracach.

${ }^{87}$ Informacje na jego temat podają: J. Hübner, 1728; 1766, tab. 778; J. Albrecht, IV. Ahnentafel..., s. 36; F. K. Wißgrill, XIX/XX, s. 187-188. Wszyscy są zgodni, że był on żonaty z Barbara, córką Jana von Ungnad; tamże.

${ }^{88}$ Informacje na jego temat podają: J. Hübner, 1728; 1766, tab. 779; J. Albrecht, IV. Ahnentafel..., s. 38-39; F. K. Wißgrill, XIX/XX, s. 191. Wszyscy są zgodni, że był on żonaty z Barbara, córką Krzysztofa von Rottal, barona von Thalborg; tamże.

${ }^{89}$ Informacje na jego temat podają: J. Hübner, 1728; 1766, tab. 779; J. Albrecht, IV. Ahnentafel..., s. 39-40; F. K. Wißgrill, XIX/XX, s. 193 i n. Wszyscy są zgodni, że był on żonaty z Małgorzata, córką Wolfganga von Staubenberga, wyższego dziedzicznego cześnika Styrii; tamże.

${ }^{90}$ Informacje na jego temat podają: J. Hübner, 1728; 1766, tab. 779; J. Albrecht, IV. Ahnentafel..., s. 41-42; F. K. Wißgrill, XIX/XX, s. 191 i n. Informacje o posiadaniu przez niego dwóch żon podają tylko Albrecht i Wißgrill, Hübner zna tylko jego drugą żonę. Pierwsza żona nosiła imię Barbara i pochodziła z rodu von Baumkirchen zu Schleuming (tak Albrecht, u Wißgrilla zu Schleinig). Drugą była Katarzyna von Hoyos, wcześniej zamężna za Gotthardem Strein zu Schwarzenau, potem jeszcze za Kasparem zu Lodron.

${ }^{91}$ Informacje na jego temat podają: J. Hübner, 1728; 1766, tab. 779; J. Albrecht, IV. Ahnentafel..., s. 42; F. K. Wißgrill, XIX/XX, s. 192. Wszyscy są zgodni, że był on żonaty z Barbarą Hoffmann(in), baronówną von Gruenpüch(e)l und Strechau, wdową po Zygmuncie von Lodron; tamże. 
1571 r. w Mannersdorf. Na dworze wiedeńskim pełnił funkcję radcy rządowego ${ }^{92}$. Pozostawił syna Krzysztofa IV, cesarskiego komornika i wyższego stolnika, zm. on bezpotomnie w roku $1616^{93}$.

Przechodząc do młodszej linii Jerzego IV, spośród sześciu jego synów trzeba zwrócić uwagę na trzech starszych. Baltazar II, baron na Wilkenberg, zmarł w roku $1544 \mathrm{w}$ niewoli tureckiej u Sulejmana II, bezpotomnie $^{94}$. To ostatnie można też powiedzieć o jego bracie Wilhelmie III (IV), panu na Kirschlag 95 . Najsłynniejszą postacią był niewątpliwie Andrzej I, ur. około roku 1510, zmarły w roku 1558, baron na Raabs i Krummbach. W roku 1540, gdy cesarz Karol V na stałe przeniósł się do Madrytu, uczynił Andrzeja I namiestnikiem cesarstwa rzymskiego narodu niemieckiego, którą to funkcję sprawował on do roku 1544. Później, w latach 15451558, był starostą krajowym Dolnej Austrii ${ }^{96}$.

Spośród dwanaściorga dzieci Andrzeja I zwrócimy uwagę na pierworodnego Zygmunta III, barona na Dobersberg, zm. w roku 1596, radcę kamery nadwornej Dolnej Austrii, który pozostawił liczne potomstwo (osiem córek i dziewięciu synów, z których ośmiu zmarło jednak w młodości $)^{97}$. Najbardziej znanym synem Andrzeja I był niewątpliwie Mikołaj.

${ }^{92}$ Informacje na jego temat podają: J. Hübner, 1728; 1766, tab. 779; J. Albrecht, IV. Ahnentafel..., s. 42-43; F. K. Wißgrill, XIX/XX, s. 192 i n. Hübner, 1728; 1766, tab. 779, informuje, że jego żoną była Elżbieta von Hoyos, w wyd. 1766, jako jedyny podaje imię jej ojca Jan. J. Albrecht dodaje, że był on baronem von Stüchenstein. J. Albrecht, IV. Ahnentafel..., s. nn.

${ }^{93}$ Informacje na jego temat podają: J. Hübner, 1728; 1766, tab. 779; J. Albrecht, IV. Ahnentafel..., s. 43-44; F. K. Wißgrill, XIX/XX, s. 192 i n. Hübner, 1728; 1766, tab. 779, informuje, że jego żoną była Anastazja, córka hr. Baltazara von Soron. J. Albrecht, IV. Ahnentafel..., s. 44, twierdzi, że owa Anastazja to córka hr. Baltazara von Biglia, a poprawia ich Wißgrill podając, że Anastazja to córka hr. Baltazara von Trautson.

${ }^{94}$ Informacje na jego temat podają: J. Hübner, 1728; 1766, tab. 779; J. Albrecht, IV. Ahnentafel..., s. 45; F. K. Wißgrill, XIX/XX, s. 195.

${ }_{95}$ Informacje na jego temat podają: J. Hübner, 1728; 1766, tab. 779; J. Albrecht, IV. Ahnentafel..., s. 45; F. K. Wißgrill, XIX/XX, s. 195.

${ }^{96}$ Istotne błędy czyni F. K. Wißgrill, Puchheim..., s. 196, który błędnie tytułuje brata Karola V Ferdynanda I cesarzem w 1544 r., był nim dopiero w 1556 r. J. Hübner, 1728; 1766, tab. 779; J. Albrecht, IV. Ahnentafel..., s. 45-46, ten zwie Ferdynanda słusznie królem [Czech i Węgier]; F. K. Wißgrill, XIX/XX, s. 196 gubią się w małżeństwach Andrzeja I. Tylko J. Albrecht, IV. Ahnentafel..., s. nn, wie, że Andrzej I miał trzy żony (J. Hübner zna drugą i trzecią, F. K. Wißgrill tylko trzecią). Pierwszą żoną była Prakseda, córka Bernarda III, hr. von Everstein, drugą Maria Elżbieta, córka hr. Jerzego Ruperta von Herberstein (na tab. 690, wyd. 1766 Hübner zamienia Jerzego Ruperta na Jerzego IV), trzecią Barbara, córka Jana Ungnada von Weissenwolf.

${ }^{97}$ Informacje na jego temat podają: J. Hübner, 1728; 1766, tab. 779; J. Albrecht, IV. Ahnentafel..., s. 46; F. K. Wißgrill, XIX/XX, s. 196 i n. Wszyscy są też zgodni, że był on żonaty z Florentyną (u Wißgrilla także pod imieniem Florencji), córką Zygmunta von Khevenhüller; tamże. 
Na jego życie istotne piętno wywarła epoka, na którą przypadło jego życie. Prawie wszyscy omawiani dotychczas członkowie domu Raabs byli katolikami, natomiast Mikołaj zafascynował się nowinkami religijnymi płynącymi z Rzeszy i przeszedł na luteranizm, co ściągnęło na niego zemstę katolików ${ }^{98}$. Stał się najbardziej tragiczną postacią w rodzie von $\mathrm{Pu}-$ chheim, jego głośna śmierć obiegła Europę w roku 1591, kiedy to fanatyk katolicki go zasztyletował ${ }^{99}$. Ostatnim synem Andrzeja I był Adam, baron na Carlsstein, dolnoaustriacki przedstawiciel ziemstwa, zm. 5 października 1608 r., którego potomstwo nie sprawowało już funkcji urzędniczych ${ }^{100}$. Jerzy Ehrereich, najbardziej znany z synów Mikołaja I, zm. w roku 1612 , był zawodowym żołnierzem ${ }^{101}$. Tej samej profesji poświęcił się jego najmłodszy syn Adolf, który najął się do służby w wojsku cudzoziemskiego autoramentu za panowania Zygmunta III Wazy, potem po wybuchu wojny trzydziestoletniej udał się do cesarstwa i w bitwie pod Lützen w roku 1632 dostał się do szwedzkiej niewoli. Został zastrzelony w roku 1639 podczas tłumienia tumultu w Pradze ${ }^{102}$. Jego syn Adolf Ehrenreich odzyskał zaufanie cesarskie, będąc wyższym stolnikiem i członkiem cesarskiej rady wojennej. Zmarł 27 października 1664 r. ${ }^{103}$ Za jego życia zmarło siedmiu jego synów, a najmłodszy Franciszek Antoni Augustyn był biskupem Wiener Neustadt ${ }^{104}$. Za zgodą papieża zrzucił sutannę

$98 \mathrm{http}: / /$ geschichte.landesmuseum.net/index.asp?contenturl=http://geschichte.landesmuseum.net/personen/personendetail.asp__id=964088514 [dostęp: 16.07.2015].

${ }^{99}$ Informacje na jego temat podają: J. Hübner, 1728; 1766, tab. 779; J. Albrecht, IV. Ahnentafel..., s. 46; F. K. Wißgrill, XIX/XX, s. 201 i n. Wszyscy są zgodni, że był on żonaty ze swoją daleką kuzynką Barbara, córką Michała Ludwika von Puchheim; tamże.

${ }^{100}$ Informacje na jego temat podają: J. Hübner, 1728; 1766, tab. 779; J. Albrecht, IV. Ahnentafel..., s. 46; F. K. Wißgrill, XIX/XX, s. 200. Hübner i Wißgrill są zgodni, że był on dwukrotnie żonaty: po raz pierwszy z Anną, córką barona Krzysztofa von Thannhausen i po raz drugi ze swoją daleką kuzynką Barbara, córką Wolfganga von Puchheim (tej nie zna Albrecht); tamże.

${ }^{101}$ Informacje na jego temat podają: J. Hübner, 1728; 1766, tab. 779; J. Albrecht, IV. Ahnentafel..., s. 46 i 49; F. K. Wißgrill, XIX/XX, s. 204. Wszyscy są zgodni, że był on żonaty z Justyna, córką hr. Krzysztofa von Althann; tamże.

${ }^{102}$ Informacje na jego temat podają: J. Hübner, 1728; 1766, tab. 779; J. Albrecht, IV. Ahnentafel..., s. 49-50; F. K. Wißgrill, XIX/XX, s. 204. Wszyscy są zgodni, że był on dwukrotnie żonaty: po raz pierwszy z Małgorzatą von Neuhausen zu Greiffenfels i po raz drugi z Marią Teresa, hr. zu Mörsberg; tamże.

${ }^{103}$ Informacje na jego temat podają: J. Hübner, 1728; 1766, tab. 779; J. Albrecht, IV. Ahnentafel..., s. 50-51; F. K. Wißgrill, XIX/XX, s. 204 i n. Wszyscy są zgodni, że był on żonaty z Teresą, córką hr. Jerzego Achacego von Losenstein; tamże.

${ }^{104}$ Informacje na jego temat podają: J. Hübner, 1728; 1766, tab. 779; J. Albrecht, IV. Ahnentafel..., s. 51-52; F. K. Wißgrill, XIX/XX, s. 205-206. Na koniec poślubił hrabiankę Judytę von Herson. 
i ożenił się, ale zmarł bezpotomnie 13 października 1718 r. - i tak potężny ród wygasł...

Podsumowując, omawiany ród piastował przez całe wieki urząd stolnika w Austrii. Jego przedstawiciele rozpoczęli swoją karierę w zamierzchłych czasach, w wieku XI, jako przybysze z Hesji. Stali się następnie ministeriałami, by wybić się do roli wiernych stronników habsburskich, pełniących najwyższe godności na dworze wiedeńskim.

\section{Bibliografia}

\section{Źródła}

Gabrieli Bucelini Germania Topo-Chrono-Stemato-Graphica Sacra et Prophana, In qua Brevi Compendio Multa disticte explicantur, Ulmae 1655.

Gabrieli Bucelini Germania Topo-Chrono-Stemato-Graphica Sacra et Prophana, In qua Brevi Compendio Multa disticte explicantur, Ulmae 1662.

\section{Źródła internetowe}

http://www.puchheim.de/index.php?id=0,22 [dostęp: 16.07.2015 r.]. http://geschichte.landesmuseum.net/index.asp?contenturl=http://geschichte.

landesmuseum.net/personen/personendetail.asp__id=964088514 [dostęp: 16.07.2015 r.].

\section{Opracowania}

Albrecht J., IV. Ahnentafel. 31. Die Puchheime, [w:] Taschenbuch für die vaterländische Geschichte. Herausgegeben durch die Freyherren von Hormayr und Mednyansky. Zehnter Jahrgang, Wien 1829.

Hübner J., Genealogische Tabellen nebst darzu gehörigen Genealogischen Fragen, zur Erläuterung der politischen Historie, mit sonderbahrem Fleiße zusammen getragen, und vom Anfange bis auf diesen Tag continuiret. Dritter Theil. Mit Königl. Polnischen und Churfl. Sächsischen sonderbahrem Privilegio, Lepzig 1728.

Koranyi K., Powszechna historia państwa i prawa w zarysie, Warszawa 1955.

Kruszewski T., Ród wolnego rycerstwa Rzeszy Frei von Dehrn w stużbie hrabiów von

Nassau. Studium historycznoprawne i genealogiczne, AUWr..., Prawo..., SHP, Wrocław [w druku].

Kruszewski T., Rycerz Dietger z Dehrn i jego ślascy potomkowie do końca średniowiecza, AUWr, No 3602, Prawo CCCXVI/2, SHP, Wrocław 2014.

Reingrabner W., Die Herren von Puchheim auf Horn (Fortsetzung und Schluß), „Das Waldviertel, Neue Folge" 1965, Nr. 3/4.

Reingrabner W., Die Herren von Puchheim auf Horn und Wildberg. Beiträge zu ihrer Genealogie, „Das Waldviertel, Neue Folge” 1965, Nr. 1/2.

Sinapius J., Schlesischer Curiositäten Erste Vorstellung, Darinnen die ansehnlichen Geschlechter Des Schlesischen Adels, Mit Erzehlung Des Ursprungs, der Wappen, Genealogien, der qualificirtesten Cavaliere, der Stamm-Häuser und Güter 
beschrieben, Und dabey viele, bißhero ermangelte Nachrichten von Edlen Rittern und löblichen Vor-Eltern, aus alten brieflichen Urkunden und bewährten MSCtis zum Vorschein gebracht werden. Fleischerische Druckerey, Leipzig 1720.

Tepperberg Ch., Die Herren von Puchheim im Mittelalter. Beiträge zur Geschichte des landsässigen Adels von Niederösterreich, Wien 1978.

Weltin M., Die Anfänge der Herren von Puchheim in Niederösterreich, [w:] Festschrift Heide Dienst zum 65. Geburtstag. Heausgeggeben von Anton Eggendorfer, Christian Lackner und Wilibald Rosner, St. Pölten 2004.

Wißgrill F. K., Puchheim, opublikowane w cyklu Schauplatz des niederösterreichischen landsässigen Adels vom Herren- und Ritter-Stande vom IX. bis zum Ende des XVIII. Jahrhunderts, [w:] Jahrbuch der k.k. heraldischen Gesellschaft Adler zu Wien, Jahrgang XIV, Wien 1887. 